\title{
Estimation of Stature from the Length of Forearm in a Population in Nedungolam
}

\section{Town in Kerala}

Manoj Balachandran* and Vina Ravi Vaswani

Department of Forensic Medicine, Yenepoya University, Deralakatte, Mangalore, Karnataka, India

*Corresponding author: Manoj Balachandran, Professor, Department of Forensic Medicine, Yenepoya University, Deralakatte, Mangalore, Karnataka, India

\section{Introduction}

Identification of the individual is one of the most important aspects of forensic investigation. Stature is an important data in identification. When only some part of the body is available, stature estimation becomes difficult. The factors which play an important role in human development and growth are racial, ethnic and nutritional factors. Nedungolam is the Northern border town of Paravur municipality in the Kollam district of Kerala state, India. Estimation of stature from the length of forearm has not been done in the present area of study so far and hence this study is quite useful.

Previous accessible records can be used for comparison for the identification of human beings. Prediction of stature from long bones holds a central position in Forensic Anthropology. There are two methods used for stature reconstruction i.e., anatomical and mathematical methods. Anatomical method requires the complete skeleton whereas mathematical method can be done even with a single bone. In the present study, an attempt has been made to formulate multiplication factors and regression equations for stature estimation among subjects belonging to Nedungolam town of Kollam district in Kerala.1 Osteological or dental examination can be used for identification. To identify a person assessment of age and sex are used in forensic examinations.

Stature, age, sex, and ancestry will help to identify a person among victims in forensic investigations. The different body parts have a relationship which can help a forensic scientist to calculate stature from mutilated and dismembered body parts in forensic examinations. This helps in events of murders, accidents or natural disasters. Stature can even be estimated from feet or foot prints, imprints of the hand or from a shoe left at the scene of a crime.

In putrefied, mutilated and extensively charred bodies, conventional indicators and routine methods of identification may not yield the desired results. Mutilated and fragmentary remains are only available due to mass disasters in some cases. The relationship of every body part with stature is more or less constant. Many studies have found a positive correlation between stature and hand dimensions. The relationship between a particular body part and stature will be different for the same race belonging to different areas. The formula for stature estimation has to be population specific.

\section{Review of Literature}

Stature is one of the important parameters which contributes to the identification of a person even after death.1 The study titled "Estimation of stature from forearm ength in North Indians- An Anthropometric study" by Bikramjeet Singh et al. (2013) has made an attempt to formulate multiplication factors and regression equations for stature estimation among subjects belonging to different areas of North India. The study was carried out on 400 subjects ( 200 males and 200 females). It was found that males exhibit greater dimensions than females for forearm length and stature. Males exhibit greater mean multiplication factor for forearm length than females from North India. There is a positive correlation between stature and upper arm length. The regression equations and multiplication factors derived in the study are quite handy for use by lay public like police [1].

The study done by Song-in et al., stresses the importance of estimation of stature from incomplete human remains for the purpose of identification. The estimated stature 
may be used to narrow down the search among missing person's list. The present study gives appropriate regression equations to estimate stature from percutaneous forearm length for Thai children aged between 5 and 19 years. The subjects did not have any physical deformities. Stature was measured using a stadiometer and forearm length using a digital caliper. The results in the present study showed high correlation between stature and forearm length in both sexes. The results obtained in this study can be used for the estimation of stature from forearm length in Thai children [2].

The background of the study "Estimation of stature from the study of ulna in Maharashtrian population" by Bamne et al. (2015) emphasises that stature has an important place in the field of Forensic Medicine and Anthropometry. The study made an attempt to estimate linear regression equation from the length of ulna. There were 200 study subjects (100 men and 100 women) of Maharashtrian population with age ranging from 20 to 25 years who were in the Department of Anatomy, Krishna Institutes of Medical Sciences University, Karad, Maharashtra, India. The study revealed a positive correlation between total height of individuals and length of ulna which was 0.73 for men and 0.70 for women. The study proved quite reliable in the estimation of stature from the length of ulna in forensic examinations [3].

The study by Poorhassan M et al. (2017) evaluates the relation between forearm length and height. The study population included 100 male and 100 female Iranian medical students. Relation between forearm length and stature were estimated using linear regression analysis. The mean age of subjects was $22+/-2.21$ years. The study found a correlation between height and forearm length of all subjects. Linear regression also showed a relation between height and upper arm length of subjects. Thus it proved that forearm length was a moderate predictor of stature of medical students in Iranian population [4].

This study "Estimation of stature from anthropometry of hand: an interesting autopsy-based study in Madhya Pradesh, India" by Goswami et al. (2016). Height is the central aspect of anthropo-forensic examination. The human hand is mainly used for these investigations. Hand length can also be used to calculate ideal body weight and body surface area in either sex. This study was conducted in the mortuary of Department of Forensic Medicine, Mahatma Gandhi Memorial Medical College and M.Y. Hospital, Indore (M.P.), India from September 2014 to September 2015. The study was conducted on 250 male and 250 female deceased individuals. The average age of males was 38 and that of females taken for the study was 34 years. Mean hand length in males was greater on the right side and in females on the left side. Hand breadth was more on right side in males and on the left side in females. Mean height in males was 163 $\mathrm{cm}$ and $155 \mathrm{~cm}$ in females [5].

The study "Estimation of stature from the hand and foot measurements in a rare tribe of Kerala State in India" by Geetha et al. (2015) was undertaken on the Vettuvar group of tribes of Kasargode district of Kerala State, India and explores the usability of the dimensions of hands and feet as predictors of stature. This study is the first ever documented study on the tribes of Kasargode district, Kerala. The study subjects were 100 males and 100 females in the age group 20-30 years. A sliding caliper was used for the measurements of hand and feet dimensions. Stature was measured using Stadiometer [6].

An attempt to calculate the stature length from ulna length among Kurdish racial subgroup living in Iran was done in the study "Stature estimation and formulation of based on ulna length in Kurdish racial subgroup" by Ghanbari et al. (2016). 50 females in the age group 19-24 years were selected for the study. A digital sliding caliper was used for taking ulna length. Vertex to floor length was taken as height. Height was also calculated using linear regression formula. The derived formula was population specific to the Kurdish racial subgroup. This study also threw light on the range of ulna length in girls of Kurdish ethnic subgroup. It can be used for further investigations on ethnic subgroups living in Iran [7].

The study "Estimation of the height of an individual to the forearm length" by Sandhya et al. (2016) compared the height of the individual to the forearm length. The estimation of stature from the skeleton bears immense importance in forensic sciences. After analysis of the parameters a positive correlation between height of individuals and forearm length was found. The regression formula used in this study is of immense help to forensic sciences, anatomist and clinicians. Future studies can focus on estimating the stature from different body parameters based on this study [8].

Estimation of Stature from the Measurement of Forearm, Hand, Leg, and Foot Dimensions in Uttar Pradesh Region done by Yadav et al. (2018). Measurement of human body and its different parts are used in the detection and correction of body defects, preparation for cosmetic surgeries and estimation of general health. It can also be used to identify criminals. This study was done to find out a correlation between the length of forearm, hand, leg and foot with stature. The study was conducted on students aged between $17 \& 21$ years of both genders. Sample size

Citation: Manoj Balachandran* and Vina Ravi Vaswani. Estimation of Stature from the Length of Forearm in a Population in Nedungolam Town in Kerala.

Op Acc J Bio Sci \& Res 7(1)-2021.

DOI: 10.46718/JBGSR.2021.07.000176 
was 200, 100 males and 100 females. Standard height measuring machine and tape were used. Of the parameters used leg length showed the highest correlation and foot length showed the least correlation with stature. This study data is helpful in medicolegal cases, among people of different regions when only some parts of the body are available [9].

The study titled "A model for individual height estimation from forearm length in natives of Kerman, Iran" done by Vaghefi et al. (2014) was done to find out the correlation between forearm length and height in natives of Kerman. It was a cross sectional study of 150 cases with 75 males and 75 females (aged 18 to 22 years) of Kermanian population. Height and left forearm length were measured in standard positions. Linear regression analysis was used in this study. There was a significant difference in the height of cases between two sex groups. There was significant difference in the forearm length of sex groups. A correlation between height and forearm length of male and female cases were also noticed. Forearm length was found to be a suitable factor for height estimation. It was a moderate predictor of height in native males and females of Kerman [10].

\section{Research Question}

Is there a correlation between the length of forearm and the height of an individual?

\section{Objectives}

The objectives of this study are

1. To determine sexual dimorphism in estimating stature from the length of forearm.

2. To derive a formula for the estimation of stature from the length of forearm.

\section{Study Design \& Methodology}

The study subjects were 200 healthy adult males and females of Nedungolam town in Kollam district, Kerala. The present study was aimed at measuring the stature from the length of forearm.

1. Method of Collection of Data: Informed written consent was obtained from the subjects.

2. Measurement of Stature Using Stadiometer: It was measured as vertical distance from the vertex to the foot. Measurement was taken by making the subject to stand erect on a horizontal resting plane, on the stadiometer bare footed. Palms of hand turned inwards and fingers horizontally pointing downwards and head oriented in eyeear-eye plane (Frankfurt Plane). The movable rod of the stadiometer was brought in contact with vertex in the mid sagittal plane (Figure 1).

3. Measurement of Forearm Length with Measuring Tape: The forearm length will be measured using a standard plastic measuring tape and will e taken as the distance between the midline of the crease of the elbow and the midline of the most distal crease of the wrist, just below the hand (Figure 2).

4. Sample Size: Considering the correlation between the height of the individual and length of forearm minimum sample size required was

5. Statistical Analysis: For the first objective of sexual dimorphism in estimating stature from the length of right index finger logistic regression can be used. For the second objective of estimating stature from the length of right index finger simple linear regression can be used for males and females.

6. Source of Data: Patients who visited various OPD departments of Taluk Hospital, Nedungolam, Kollam district, Kerala.

7. Inclusion Criteria: Subjects aged between 18-60 years of Indian origin.

8. Exclusion Criteria: Subjects having significant diseases, congenitally malformed limbs, metabolic disorders and developmental defects.

Observation and Results:

\section{(Tables 1-10)}

\section{Discussion}

The present study was done on patients who visited the OPD of Taluk Hospital, Nedungolam, who were aged between 18-60 years and were of Indian origin. The forearm length was measured using a Measuring tape and the stature of the individual by a stadiometer. The exact age of the person and the area of residence were identified from his/her government issued identity card. The study showed a significant correlation between the length of forearm and the stature of the individual. The table given below shows a comparison between different studies that were used as reference and the present study (Table 11).

In the study titled "Estimation of stature from forearm length in North Indians- An Anthropometric study" it was found that male North Indians exhibit greater dimensions than the females for the forearm length and the stature. Stature was measured using an anthropometric board and forearm length using a measuring tape. Also greater mean Multiplication factor for forearm length were found in males

Citation: Manoj Balachandran* and Vina Ravi Vaswani. Estimation of Stature from the Length of Forearm in a Population in Nedungolam Town in Kerala. 


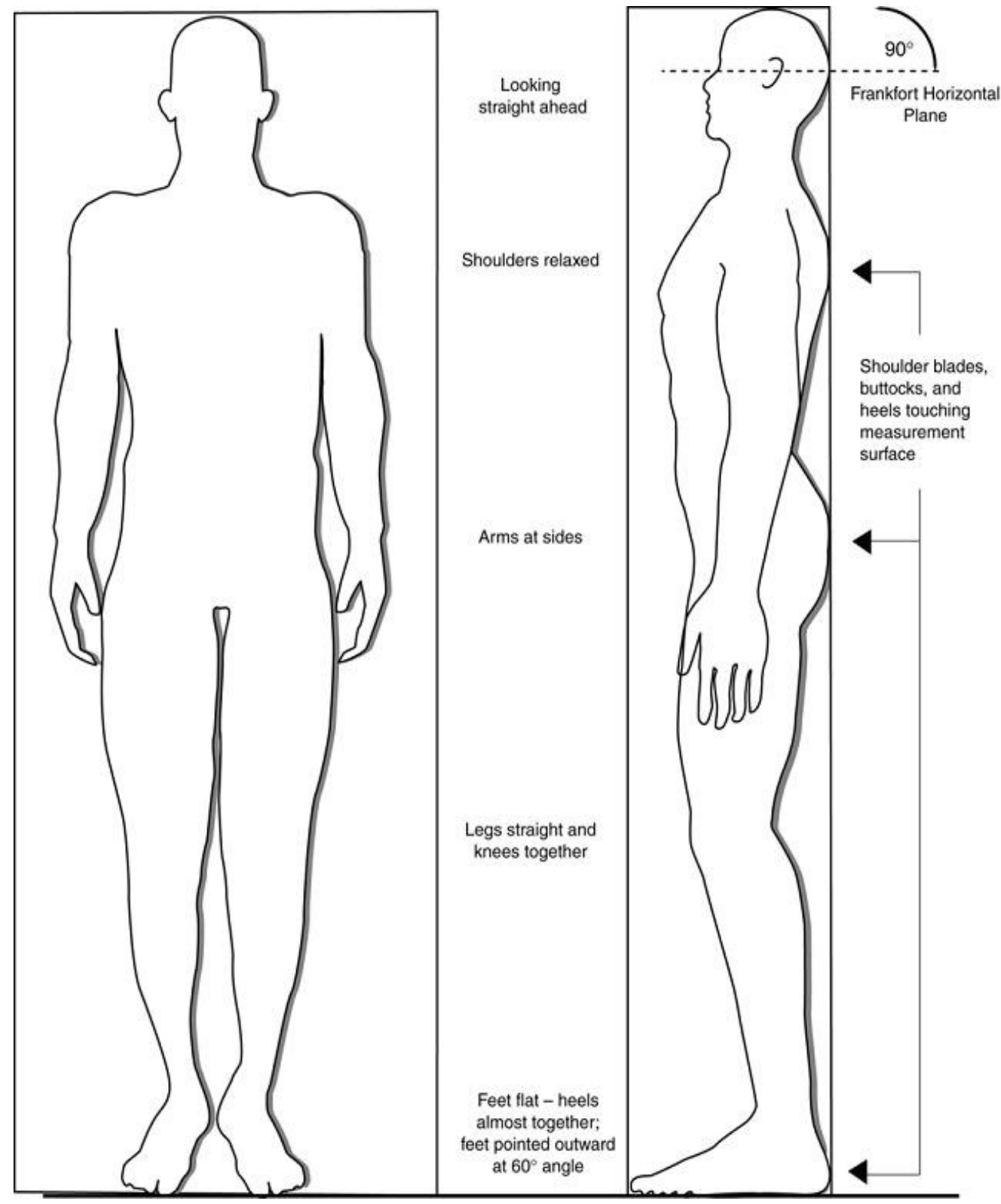

Figure 1: Measurement of height in Frankfurt plane.

Citation: Manoj Balachandran* and Vina Ravi Vaswani. Estimation of Stature from the Length of Forearm in a Population in Nedungolam Town in Kerala.

Op Acc J Bio Sci \& Res 7(1)-2021. 


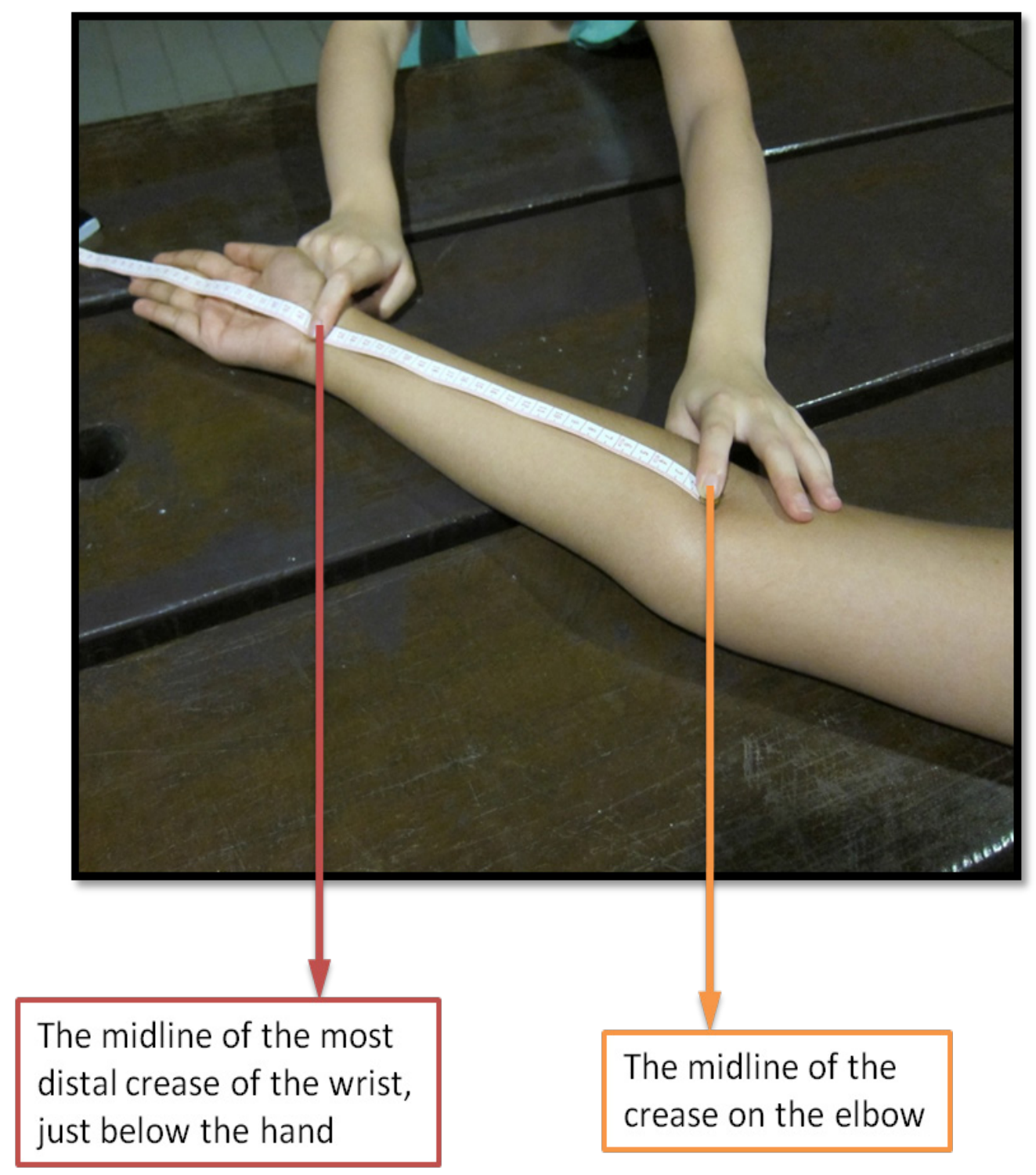

Figure 2: Measurement of the length of forearm using Measuring tape. 
Table 1: Sex (Male/ Female).

\begin{tabular}{|c|c|c|c|c|}
\hline & Frequency & Percent & $\begin{array}{c}\text { Valid } \\
\text { Percent }\end{array}$ & $\begin{array}{c}\text { Cumulative } \\
\text { Percent }\end{array}$ \\
\hline Valid Males & 103 & 51.5 & 51.5 & 51.5 \\
\hline Females & 97 & 48.5 & 48.5 & 100 \\
\hline Total & 200 & 100 & & \\
\hline
\end{tabular}

Table 2: Descriptive Statistics.

\begin{tabular}{|c|c|c|c|c|c|}
\hline & N & Minimum & Maximum & Mean & $\begin{array}{c}\text { Std. } \\
\text { Deviation }\end{array}$ \\
\hline Age (Years) & 200 & 18 & 60 & 39.93 & 12.085 \\
\hline $\begin{array}{c}\text { Right forearm } \\
\text { length(cm) }\end{array}$ & 200 & 20 & 32 & 24.935 & 1.8221 \\
\hline $\begin{array}{c}\text { Left forearm } \\
\text { length(cm) }\end{array}$ & 200 & 21 & 32 & 24.875 & 1.8538 \\
\hline \begin{tabular}{c} 
Height(cm) \\
\hline $\begin{array}{c}\text { Valid N } \\
\text { (litewise) }\end{array}$
\end{tabular} & 200 & 139 & 184 & 159.88 & 9.293 \\
\hline
\end{tabular}

Table 3: Symmetric Measures.

\begin{tabular}{|c|c|c|c|c|}
\hline & Value & $\begin{array}{c}\text { Asymptotic } \\
\text { Standardized } \\
\text { Error }^{\mathbf{a}}\end{array}$ & $\begin{array}{c}\text { Approximate } \\
\text { Tb }\end{array}$ & Pvalue \\
\hline $\begin{array}{c}\text { Interval by } \\
\text { Pearson's R } \\
\text { Interval }\end{array}$ & 0.797 & 0.026 & 18.556 & $<0.001$ \\
\hline $\begin{array}{c}\text { Ordinal by } \\
\text { Spearson Ordinal } \\
\text { Correlation }\end{array}$ & 0.793 & 0.03 & 18.286 & $.000^{c}$ \\
\hline N of valid cases & 200 & & & \\
\hline
\end{tabular}

Table 4: Symmetric Measures.

\begin{tabular}{|c|c|c|c|c|}
\hline & Value & $\begin{array}{c}\text { Asymptotic } \\
\text { Standardized } \\
\text { Error }^{\mathrm{a}}\end{array}$ & $\begin{array}{c}\text { Approximate } \\
\text { Tb }\end{array}$ & Pvalue \\
\hline $\begin{array}{c}\text { Interval by Pearson's } \\
\text { R Interval }\end{array}$ & 0.804 & 0.026 & 19.017 & $<0.001$ \\
\hline $\begin{array}{c}\text { Ordinal by Spearson } \\
\text { Ordinal Correlation }\end{array}$ & 0.799 & 0.031 & 18.706 & $.000^{\mathrm{c}}$ \\
\hline N of valid cases & 200 & & & \\
\hline
\end{tabular}

Table 5: Coefficientsa

\begin{tabular}{|c|c|c|c|c|c|c|c|}
\hline & \multicolumn{2}{|c|}{$\begin{array}{c}\text { Unstandardized } \\
\text { Coefficients }\end{array}$} & \multicolumn{2}{c|}{$\begin{array}{c}\text { standardized } \\
\text { Coefficients }\end{array}$} & \multicolumn{2}{|c|}{$\begin{array}{c}\text { 95\% confidence } \\
\text { Interval for B }\end{array}$} \\
\cline { 2 - 8 } Model & B & Std.Error & Beta & $\mathrm{t}$ & Sig. & $\begin{array}{c}\text { Lower } \\
\text { band }\end{array}$ & $\begin{array}{c}\text { Upper } \\
\text { band }\end{array}$ \\
\hline $\begin{array}{c}\text { Male } \\
\text { (Constant) }\end{array}$ & 90.242 & 9.269 & & 9.736 & 0 & 71.855 & 108.63 \\
\hline $\begin{array}{c}\text { Right } \\
\text { forearm } \\
\text { length (cm) }\end{array}$ & 2.916 & 0.356 & 0.632 & 8.201 & 0 & 2.211 & 3.622 \\
\hline
\end{tabular}

Table 6: Coefficientsa

\begin{tabular}{|c|c|c|c|c|c|c|c|}
\hline \multirow{2}{*}{ Model } & \multicolumn{2}{|c|}{$\begin{array}{c}\text { Unstandardized } \\
\text { Coefficients }\end{array}$} & \multicolumn{2}{c|}{$\begin{array}{c}\text { standardized } \\
\text { Coefficients }\end{array}$} & \multicolumn{2}{|c|}{$\begin{array}{c}\text { 95\% confidence } \\
\text { Interval for B }\end{array}$} \\
\cline { 2 - 9 } & $\mathrm{B}$ & $\begin{array}{c}\text { Std. } \\
\text { Error }\end{array}$ & Beta & $\mathrm{t}$ & Sig. & $\begin{array}{c}\text { Lower } \\
\text { band }\end{array}$ & $\begin{array}{c}\text { Upper } \\
\text { band }\end{array}$ \\
\hline $\begin{array}{l}\text { (Constant) } \\
\text { Left forearm } \\
\text { length }(\mathrm{cm})\end{array}$ & 88.653 & 8.741 & & 10.143 & 0 & 71.314 & 105.992 \\
\cline { 2 - 9 } & 2.981 & .336 & .662 & 8.880 & 0 & 2.315 & 3.647 \\
\hline
\end{tabular}

Table 7: Coefficientsa

\begin{tabular}{|c|c|c|c|c|c|c|c|}
\hline & \multicolumn{2}{|c|}{$\begin{array}{c}\text { Unstandardized } \\
\text { Coefficients }\end{array}$} & \multicolumn{2}{|c|}{$\begin{array}{c}\text { standardized } \\
\text { Coefficients }\end{array}$} & \multicolumn{3}{|c|}{$\begin{array}{c}\text { 95\% confidence } \\
\text { Interval for B }\end{array}$} \\
\cline { 2 - 8 } Model & B & $\begin{array}{c}\text { Std. } \\
\text { Error }\end{array}$ & Beta & t & Sig. & $\begin{array}{c}\text { Lower } \\
\text { band }\end{array}$ & $\begin{array}{c}\text { Upper } \\
\text { band }\end{array}$ \\
\hline $\begin{array}{c}\text { Female } \\
\text { (Constant) }\end{array}$ & 77.322 & 8.442 & & 9.159 & 0 & 60.562 & 94.082 \\
\hline $\begin{array}{c}\text { Right } \\
\text { forearm } \\
\text { length (cm) }\end{array}$ & 3.192 & .354 & 0.679 & 9.006 & 0 & 2.488 & 3.896 \\
\hline
\end{tabular}

Table 8: Coefficientsa

\begin{tabular}{|c|c|c|c|c|c|c|c|}
\hline \multirow{2}{*}{ Model } & \multicolumn{2}{|c|}{$\begin{array}{c}\text { Unstandardized } \\
\text { Coefficients }\end{array}$} & \multicolumn{2}{|c|}{$\begin{array}{c}\text { standardized } \\
\text { Coefficients }\end{array}$} & \multicolumn{2}{|c|}{$\begin{array}{c}\text { 95\% confidence } \\
\text { Interval for B }\end{array}$} \\
\cline { 2 - 8 } & B & $\begin{array}{c}\text { Std. } \\
\text { Error }\end{array}$ & Beta & t & Sig. & $\begin{array}{c}\text { Lower } \\
\text { band }\end{array}$ & $\begin{array}{c}\text { Upper } \\
\text { band }\end{array}$ \\
\hline 1. (Constant) & 79.188 & 8.703 & & 9.099 & 0 & 61.911 & 96.465 \\
\hline $\begin{array}{c}\text { Left forearm } \\
\text { length }(\mathrm{cm})\end{array}$ & 3.126 & .367 & .658 & 8.522 & 0 & 2.397 & 3.854 \\
\hline
\end{tabular}

Citation: Manoj Balachandran* and Vina Ravi Vaswani. Estimation of Stature from the Length of Forearm in a Population in Nedungolam Town in Kerala. 
Table 9: Coefficientsa

\begin{tabular}{|c|c|c|c|c|c|c|c|}
\hline & \multicolumn{2}{|c|}{$\begin{array}{c}\text { Unstandardized } \\
\text { Coefficients }\end{array}$} & \multicolumn{2}{|c|}{$\begin{array}{c}\text { standardized } \\
\text { Coefficients }\end{array}$} & \multicolumn{2}{|c|}{$\begin{array}{c}\text { 95\% confidence } \\
\text { Interval for B }\end{array}$} \\
\cline { 2 - 8 } Model & $\mathrm{B}$ & $\begin{array}{c}\text { Std. } \\
\text { Error }\end{array}$ & Beta & $\mathrm{t}$ & Sig. & $\begin{array}{c}\text { Lower } \\
\text { band }\end{array}$ & $\begin{array}{c}\text { Upper } \\
\text { band }\end{array}$ \\
\hline $\begin{array}{c}1 . \\
\text { (Constant) }\end{array}$ & 58.540 & 5.476 & & 10.691 & 0 & 47.742 & 69.338 \\
\hline $\begin{array}{c}\text { Right } \\
\text { forearm } \\
\text { length } \\
\text { (cm) }\end{array}$ & 4.064 & .219 & .797 & 18.556 & 0 & 3.632 & 4.496 \\
\hline
\end{tabular}

Table 10: coefficientsa

\begin{tabular}{|c|c|c|c|c|c|c|c|}
\hline \multirow{2}{*}{ Model } & \multicolumn{2}{|c|}{$\begin{array}{c}\text { Unstandardized } \\
\text { Coefficients }\end{array}$} & \multicolumn{2}{c|}{$\begin{array}{c}\text { standardized } \\
\text { Coefficients }\end{array}$} & \multicolumn{2}{|c|}{$\begin{array}{c}\text { 95\% confidence } \\
\text { Interval for B }\end{array}$} \\
\cline { 2 - 9 } & $\mathrm{B}$ & $\begin{array}{c}\text { Std. } \\
\text { Error }\end{array}$ & Beta & $\mathrm{t}$ & Sig. & $\begin{array}{c}\text { Lower } \\
\text { band }\end{array}$ & $\begin{array}{c}\text { Upper } \\
\text { band }\end{array}$ \\
\hline 1. (Constant) & 59.634 & 5.286 & & 11.282 & 0 & 49.210 & 70.057 \\
\hline $\begin{array}{c}\text { Left forearm } \\
\text { length }(\mathrm{cm})\end{array}$ & 4.030 & .212 & .804 & 19.017 & 0 & 3.612 & 4.448 \\
\hline
\end{tabular}

Table 11: Comparison of the results of various studies.

\begin{tabular}{|c|c|c|c|c|}
\hline Author & Year & Sample size & Study population & Result \\
\hline Singh B et al. & 2013 & $\begin{array}{l}400 \text { (200 males and } \\
200 \text { females })\end{array}$ & $\begin{array}{l}\text { Individuals of Department of } \\
\text { Anatomy of SGRD Institute of } \\
\text { Medical Sciences and Research, Sri } \\
\text { Amritsar. }\end{array}$ & $\begin{array}{l}\text { Forearm length exhibit highly significant correlation in } \\
\text { male and female North Indians. }\end{array}$ \\
\hline $\begin{array}{l}\text { Song-in K } \\
\text { et al. }\end{array}$ & 2013 & $\begin{array}{l}45 \text { males and } 45 \\
\text { females aged between } \\
5-19 \text { years }\end{array}$ & Thai school age children & $\begin{array}{l}\text { Stature can be estimated from forearm length in } \\
\text { children. }\end{array}$ \\
\hline Bamne A et al. & 2015 & $\begin{array}{l}200 \text { healthy } \\
\text { individuals (100 men } \\
\text { and } 100 \text { women) aged } \\
\text { between 20-25 years }\end{array}$ & $\begin{array}{l}\text { Individuals in the Department } \\
\text { of Anatomy, Krishna Institute of } \\
\text { Medical Sciences University, Karad, } \\
\text { Maharashtra, India. }\end{array}$ & $\begin{array}{c}\text { There is a positive correlation between total height of } \\
\text { individuals and length of ulna. }\end{array}$ \\
\hline $\begin{array}{l}\text { Poorhassan M } \\
\text { et al. }\end{array}$ & 2017 & $\begin{array}{l}100 \text { males and } 100 \\
\text { females aged between } \\
18-25 \text { years }\end{array}$ & $\begin{array}{l}\text { Medical students from Iranian } \\
\text { population. }\end{array}$ & $\begin{array}{l}\text { Forearm length was a moderate predictor for stature } \\
\text { estimation of medical students in Iranian population. }\end{array}$ \\
\hline $\begin{array}{l}\text { Goswami R } \\
\text { et al. }\end{array}$ & 2016 & $\begin{array}{l}250 \text { deceased male } \\
\text { and } 250 \text { deceased } \\
\text { female individuals }\end{array}$ & $\begin{array}{l}\text { Mortuary of department of Forensic } \\
\text { Medicine, Mahatma Gandhi } \\
\text { Memorial Medical College and M.Y } \\
\text { Hospital, Indore. }\end{array}$ & $\begin{array}{l}\text { Mean hand length on right side were more than on left } \\
\text { side in both male and female subjects. Hand breadth on } \\
\text { right side was also more than on left side in both males } \\
\text { and females. }\end{array}$ \\
\hline Geetha G et al. & 2016 & $\begin{array}{l}100 \text { males and } 100 \\
\text { females in the age } \\
\text { group of } 20 \text {-30 years }\end{array}$ & $\begin{array}{c}\text { Vettuvar group of tribes in } \\
\text { Kasargode district of Kerala State, } \\
\text { India. }\end{array}$ & $\begin{array}{l}\text { Bilateral variations were insignificant for all the } \\
\text { measurements except foot breadth among females } \\
\qquad(\mathrm{p}<0.001)\end{array}$ \\
\hline $\begin{array}{l}\text { Ghanbari K } \\
\text { et al. }\end{array}$ & 2016 & $\begin{array}{l}50 \text { females aged } 19-24 \\
\text { years }\end{array}$ & Kurdish racial subgroup in Iran & $\begin{array}{l}\text { The derived formulae were population specific and } \\
\text { are designed for use in forensic and anthropometric } \\
\text { analysis of Kurdish racial subgroup. }\end{array}$ \\
\hline Sandhya A & 2016 & 300 subjects & iged between $18-22$ years & $\begin{array}{l}\text { By using the anthropometric measurements of hand } \\
\text { dimensions, sex can be estimated with a high accuracy. }\end{array}$ \\
\hline Yadav S et al. & 2018 & $\begin{array}{c}200 \text { students aged } \\
\text { between } 17 \& 21 \text { years }\end{array}$ & $\begin{array}{c}\text { Medical students from } \\
\text { Theerthangeer Mahaveer Medical } \\
\text { College \& research Centre, } \\
\text { Moradabad, Uttar Pradesh. }\end{array}$ & $\begin{array}{l}\text { This study will help in medicolegal cases among people } \\
\text { of different regions when only some parts of the body } \\
\text { are found. }\end{array}$ \\
\hline $\begin{array}{c}\text { Eftekar } \\
\text { Vaghefi S et al. }\end{array}$ & 2014 & $\begin{array}{c}150 \text { cases aged } \\
\text { between } 17-22 \text { years }\end{array}$ & $\begin{array}{l}\text { Kermanian natives with middle } \\
\text { socio-economic status }\end{array}$ & $\begin{array}{l}\text { The study suggests that forearm length is a suitable } \\
\text { factor for height estimation. }\end{array}$ \\
\hline Present study & 2018 & $\begin{array}{c}200 \text { subjects aged } \\
\text { between } 18-60 \text { years }\end{array}$ & $\begin{array}{l}\text { Patients attending the OPD of Taluk } \\
\text { Hospital, Nedungolam. }\end{array}$ & $\begin{array}{l}\text { A moderate correlation was found between the length of } \\
\text { forearm and stature of an individual. }\end{array}$ \\
\hline
\end{tabular}

Citation: Manoj Balachandran* and Vina Ravi Vaswani. Estimation of Stature from the Length of Forearm in a Population in Nedungolam Town in Kerala. 
than in females. Stature and upper arm length also showed positive and significant correlation.1 This study is different from our study where forearm length is used to find out stature of an individual.

In the study by Song-in $\mathrm{K}$ et al., stature and forearm lengths were measured from a total of 90 (45 males and 45 females) children in the central region of Thailand. The results show that the mean stature and all forearm lengths of males are higher than those of females; similar findings were observed in previous studies. Stature and forearm length were measured using a stadiometer and a digital caliper. The results obtained proved that forearm length can be efficiently used for stature estimation. 2 This study is similar to our present study in that forearm length is used to calculate the stature of an individual.

Bamne A et al. studied the relationship between ulnar length and the stature of an individual. This study showed higher mean values in each anthropometric measurement than among women. Standard Vernier Caliper was used for measuring ulnar length. Standard flexible steel tape was used for measuring total height of an individual. It was found that the stature of a person can be estimated with great accuracy using the length of the ulna. The regression equations can be used in artificial limb centres for construction of prosthesis required in cases of amputations. It can be helpful in biometrics and can also be used for anthropological studies. 3 This study has employed only the measurement of one of the bones of the forearm i.e., the ulna whereas in our present study the entire length of forearm is used to estimate stature.

Poorhassan $\mathrm{M}$ et al. in their study found that there was a relation between height and upper arm length of subjects in all cases. There was also a relation between stature and forearm length in male subjects. Stadiometer was used for stature measurement and standard tape for forearm length measurement. But this was not found in case of female subjects. Mean stature was higher for males than females. Forearm length was found to be a moderate predictor for stature estimation in medical students in Iranian population. 4 This study is quite similar to our present study in that forearm length is used to calculate stature.

Goswami et al.'s study can be used as baseline information for other population-based studies in the study area. Standard Vernier caliper, standard measuring tape and standard measuring scale were used for the study. This information can be used by anthropologists, forensic and other medicolegal experts to estimate the stature by the use of length and width of hand within the standard error of estimate. The differences in different populations should be used to apply such formula to other populations. 5 This study is different from our present study in that hand length and hand breadth were used for stature estimation.

The findings in the study by Geetha $G$ et al. may be used to predict stature in cases where whole length of hand and foot were not available for investigation. The data obtained can be used for getting certain population specific anthropometric indices amongst the tribal population. Sliding caliper was used for hand and feet measurements and Stadiometer was used to measure vertical height for stature estimation. This is the first ever documented anthropological work among the tribal population of Kasargode. 6 In this study stature was estimated using multiple parameters while our present study used only a single parameter for stature estimation.

Ghanbari K et al. showed the range of ulna length in girls of Kurdish ethnic subgroup and the data obtained in this study was used to estimate stature in Kurdish ethnic subgroup on the basis of ulna length. Digital sliding caliper was used to measure ulna length and height was taken when person was standing in anatomical position and head in the Frankfurt plane. It can also be used for further investigations on ethnic subgroups living in Iran.7 In this study also a single forearm bone length was used for stature estimation like the study done by Bamne et al. in 2015.

Sandhya A proved in her study that from the length of forearm the height of an individual can be estimated. Height was measured against a wall using a ruler, pencil and measuring tape. Forearm length was measured using a standard measuring tape. This study also paved way for future studies to focus on estimating height using other different body parameters. 8 This study also uses forearm length to determine stature like our present study.

The study by Yadav $\mathrm{S}$ et al. showed that second highest degree of correlation was found for forearm length with regression coefficient. A standard height measuring instrument was used for estimating stature and various other parameters of right and left sides were measured using measuring tape. The regression coefficient in this study showed stature and dimension of hand was the third most correlated value.9 This study uses multiple parameters like forearm length, hand length, leg length and foot length for stature estimation while our present study uses only a single parameter.

Eftikar Vaghefi S et al. in their study showed that forearm length was a valuable predictor for height estimation. Stadiometer and standard measuring tape were used for stature measurement and forearm length measurement

Citation: Manoj Balachandran* and Vina Ravi Vaswani. Estimation of Stature from the Length of Forearm in a Population in Nedungolam Town in Kerala.

Op Acc J Bio Sci \& Res 7(1)-2021.

DOI: 10.46718/JBGSR.2021.07.000176 
respectively. This factor was also a moderate predictor of height in native males and females of Kerman.10 This study is quite similar to our present study with respect to the parameters used and the methodology employed. The findings in the present study done on subjects in Nedungolam town in Kerala showed that there is a moderate correlation between the length of forearm and stature of an individual.

\section{Conclusion and Summary}

A moderate correlation was found between right forearm length and Height and this correlation is highly statistically significant. There is also a moderate correlation between Left forearm length and Height and this correlation is also highly statistically significant. The following formulae were derived for the estimation of stature in the study.

1. HEIGHT $(M A L E)=90.24+2.19 *$ Right forearm length

2. HEIGHT $(M A L E)=88.65+2.98 \times$ Left forearm length

3. HEIGHT (FEMALE) $=77.32+3.19 *$ Right forearm length

4. HEIGHT $($ FEMALE $)=79.18+3.12 \times$ Left forearm length

5. HEIGHT $=58.54+4.06 *$ Right forearm length

6. HEIGHT $=59.63+4.03 \times$ Left forearm length

The first four formulae exhibit the sexual dimorphism in estimating stature from the length of forearm in both the sexes. The last two formulae were common for both genders.

\section{Recommendations}

Various other parameters can be used for stature estimation like the arm length, hand length, foot length and head circumference. The study can be extended to people belonging to different races and the values compared.

\section{Limitations of the Study}

1. The study is done in a population in Nedungolam town in Kerala. This may not be a good representative sample of a universal study group.

2. A single dimension i.e., length of forearm is used to estimate stature which can reduce the accuracy.

\section{References}

1. Singh B, Kaur M, Kaur J, Singh M, Batra A (2013) Estimation of stature from forearm length in North Indians- An Anthropometric study. International Journal of Basic and Applied Medical Sciences 3(1): 201-204.

2. Song-in K, Riengrojpitak S, Tiensuwan M (2013) Estimation of Stature from Forearm Length in Thai Children. SDU Res J 6(1): 131-139.

3. Bamne A, Bamne S, Choursia R, Gohiya V (2015) Estimation of stature from length of ulna in Maharashtrian population. International Journal of Medical Science and Public Health $4(1): 65$.

4. Stature estimation from forearm length: an anthropological study in Iranian medical students (2017) Journal of Contemporary Medical Sciences 3(11): 270-272.

5. Goswami R, Thakur P, Dadu S, Rastogi A (2016) Estimation of stature from anthropometry of hand: an interesting autopsy based study in Madhya Pradesh, India. International Journal of Research in Medical Sciences 1873-1878.

6. Geetha G, Arvind Athavale S (2015) Estimation of Stature From Hand and Foot Measurements in a Rare Tribe of Kerala State in India. JOURNAL OF CLINICAL AND DIAGNOSTIC RESEARCH 9(10): HCO1-HCO4.

7. Ghanbari K, Reza Nazari A, Ghanbari A, Chehrei S (2016) Stature estimation and formulation of based on ulna length in Kurdish racial subgroup. Italian Journal of Anatomy and Embryology 121(1):43-50.

8. Sandhya A (2016) Estimation of the height of an individual to the forearm length. International Journal of Science and Research 5(8): 1532-1535.

9. Yadav S, Pathak B (2018) Estimation of Stature from the Measurement of Forearm, Hand, Leg, and Foot Dimensions in Uttar Pradesh Region. International Journal of Therapeutic Applications 35: 49-53.

10. Eftekhar Vaghefi S, Shiekhbahaei F, Mokhtari T, Khademi $\mathrm{F}$, Bahari $\mathrm{H}$, et al. (2014) A Model for Individual Height Estimation from Forearm Length in Natives of Kerman, Iran. Anatomical Sciences 11(3): 141-144.

\section{*Corresponding author: Manoj Balachandran, Email: bmanoj7@yahoo.co.in}

Next Submission with BGSR follows:

- Rapid Peer Review

- Reprints for Original Copy

- E-Prints Availability

- Below URL for auxiliary Submission Link: https://biogenericpublishers.com/submit-manuscript/ 